\title{
Pattern of Bacterial Isolates and Antimicrobial Susceptibility of Urine Culture in Men with Chronic Bacterial Prostatitis and Levels PSA Before and After Treatment
}

\author{
Krakhotkin DV ${ }^{1 *}$, Chernylovskyi VA ${ }^{2}$, Najjar Salam ${ }^{3}$ and Alper Gok ${ }^{4}$ \\ ${ }^{1}$ Central district hospital, Outpatient clinic, Kamenolomni, Rostov region, Russia \\ ${ }^{2}$ Dnipropetrovsk City, Multifield Hospital No 4, Department of urology, Dnipro, Ukraine \\ ${ }^{3}$ Center of Uronephrology and Renal Transplantation, Fundeni Clinical Institute, Bucharest, Romania \\ ${ }^{4}$ University of Health Sciences, Diskapi Yildirim Beyazit Training and Research Hospital, Department of Urology, \\ Ankara, Turkey
}

Received: September 21, 2017; Accepted: October 6, 2017; Published: October 26, 2017

*Corresponding author: Krakhotkin Denis, Central district hospital, Outpatient clinic, Sadovaya lane 23, Kamenolomni, 346480, Rostov Region, Russia. E-mail: den_surgeon@mail.ru

\begin{abstract}
Objective: To study the influence of combined antibiotic therapy on levels PSA in "grey zone" for patients with chronic bacterial prostatitis without signs prostate cancer.

Patients and Methods: In our study was presented 125 patients in aged 30-83 years with diagnosis of chronic bacterial prostatitis. We performed digital rectal examination, urine culture, transrectal ultrasound investigation of prostate, PSA analysis before and after antibiotic treatment and antimicrobial susceptibility testing. Criteria for inclusion in the trial were digital rectal examination without suspicion of urological cancers, absence of history of intravesical instrumentation and biopsy of prostate, values PSA in range from 4,0 to $11 \mathrm{ng} / \mathrm{ml}$, symptoms of chronic bacterial prostatitis, absence of abnormalities both upper and lower urinary tracts. For evaluation changes PSA before and after treatment we divided all patients on five groups with different regimen antimicrobial agents in according to results antibiotic susceptibility test.

Results: A total of 125 patients with chronic bacterial prostatitis and high level of PSA were estimated by culture of urine for determination spectrum of isolated microorganisms and pattern susceptibility to antimicrobial agents. The average (mean \pm standard deviation) age of all men in this study was $59.6 \pm 12.7$ years. The non-clostridial, non-spore forming anaerobic microorganisms, the taxonomic structure of chronic bacterial prostatitis were more often represented by Peptococcus spp (37,8\%), Propionibacterium spp (36\%), Eubacterium spp (47,2\%), Veillonella spp $(24,4 \%)$ with average level of bacteriuria $\log 1,5 \mathrm{CFU} / \mathrm{ml}, \log 2,6 \mathrm{CFU} / \mathrm{ml}, \log 3,2 \mathrm{CFU} / \mathrm{ml}, \log 1,9 \mathrm{CFU} / \mathrm{ml}$, respectively. In the group of cougulasenegative staphylococci predominated S.epidermidis (29,5\%), S.haemalyticus (20,8\%), S.aureus (12\%) with mean level of bacteriuria Log 1,5 CFU/ $\mathrm{ml}, \log 1,9 \mathrm{CFU} / \mathrm{ml}, \log 1,8 \mathrm{CFU} / \mathrm{ml}$, respectively. In five groups patients which divided in depending from chosen regimen of combined antibiotic treatment in according results susceptibility testing to antimicrobial agents, the changes of level PSA were following : in I group (25 patients) 7,34 $\pm 2,6,95 \% \mathrm{CI}[6.27-8.41]$ before and $2.26 \pm 1.02,95 \%$ CI [1.84 - 2.68] after treatment, administration ; in II group (22 patients) $7.20 \pm 1.76,95 \%$ CI (6.42 - 7.98) before and $1.8 \pm 0.84,95 \%$ CI (1.43 - 2.17) after; in III groups (26 patients) $7.05 \pm 1.35,95 \%$ CI (6.5 - 7.6$)$ before and $1.57 \pm 0.89$, $95 \% \mathrm{CI}(1.21$ - 1.93) after treatment ; in IV group (24 patients) $7.51 \pm 1.39,95 \% \mathrm{CI}(6.92-8.1)$ before and $1.45 \pm 0.93,95 \% \mathrm{CI}(1.29-1.61)$ after treatment ; in V group (28 patients) $7.11 \pm 1.16,95 \% \mathrm{CI}(6.66-7.56)$ before and $1.48 \pm 0.8695 \% \mathrm{CI}$ (1.15 - 1.81) after treatment . After 3 and 6 months we performed the repeat measurement of level PSA and there was no any elevation higher than $>4 \mathrm{ng} / \mathrm{ml}$.

Conclusions: In patients with baseline level PSA in range $4-10 \mathrm{ng} / \mathrm{ml}$ provided that possibility of PCa is excluded by digital rectal examination and transrectal ultrasound investigation, administration of combined antibacterial therapy with fluoroquinolones in account of pattern of isolated microorganisms and results susceptibility to antibiotic can lead to significant decrease level PSA and microbiological eradication pathogens and to avoid unnecessary biopsies of prostate.
\end{abstract}

Key words: Chronic Bacterial Prostatitis; PSA; Antibiotic Treatment; Biopsy of Prostate 


\section{Abbreviations}

CBP-Chronic Bacterial Prostatitis; PCA- Prostate Cancer; PSA- Prostate Specific Antigen; TRUS-Transrectal Ultrasound Investigation; DRE- Digital Rectal Examination

\section{Introduction}

Chronic bacterial prostatitis is a troublesome disease showing an overall clinical 28 and microbiological response to fluoroquinolones, the antibiotics of choice, of only $60 \%$ [1]. Prostatitis exhibits a bimodal peak of incidence, with men between 20 and 40 years of age or older than 60 years afflicted most commonly [2]. Despite progress in the management of chronic bacterial prostatitis, many cases are undertreated and a significant number relapse. The reasons are practically unknown and include host, bacterial, and treatment related factors. While patients at increased risk for CBP recurrence and local (organspecific) conditions have been clearly specified, bacterial- and treatment-related factors remain relatively unclarified [3]. In terms of prevalence of chronic prostatitis is in line with such diseases as diabetes and ischemic disease heart, and has a tremendous impact on the quality of life of the patient. Thus, the fact that chronic prostatitis is one of the most pressing problems of urology all over the world, not is in doubt [4]. The prevalence of CBP is very low, with only $5-10 \%$ of all prostatitis cases suffering from this condition. One of the characteristics of this prostatitis is that it is often accompanied by urogenital infection. The pathogens responsible for this syndrome includes gram-positive and gramnegative bacteria, of which, gram-positive often occur transiently, and pathogens that result in complex urogenital tract infections [5]. The major cause for inducing acute bacterial prostatitis is Escherichia coli, which is accompanied by different kinds of other microorganisms such as Pseudomonas aeruginosa, Enterococcus, Proteus, Klebsiella, Enterobacter, and Serratia species [6]. Approximately $10 \%$ of men suffering an episode of acute bacterial prostatitis continue to suffer chronic bacterial prostatitis and a further $10 \%$ progress to chronic prostatitis/chronic pelvic pain syndrome [7]. Several factors have been associated with chronic prostatitis, including smoking, high caloric diet with low consumption of fruit and vegetables, and slow digestion, although the pathogenesis and aetiopathogenic mechanisms of this disease have yet to be fully elucidated. Clearly, by definition both acute and chronic bacterial prostatitis are caused by prostatic infection, but proper and effective treatment of both conditions requires accurate diagnosis. There is still debate, however, over the pathogenic causes of Category III and IV prostatitis syndromes, the aetiology of which may be immunological, neurological, psychosomatic or anatomical in nature [8]. The pathogens associated with chronic bacterial prostatitis are essentially the common uropathogens, including Escherichia coli and Klebsiella spp [9]. Konstantinos Stamatiou and Drosos E. Karageorgopoulos in one study showed that Enterococcus faecalis and Proteus were susceptible to all antimicrobials in about half of the isolates (54.5 and $50 \%$, respectively), raises questions about the judicious use of antimicrobials, while the relatively high proportion of Grampositive bacteria (35.7\%) in positive cultures [9]. Habits and sexual behaviors suggested to predispose to chronic prostatitis were documented in less than half of the cases in this study indicating thus that other factors than those traditionally associated with chronic prostatitis may predispose to its development [10]. The question of the role of gram-positive bacteria, as well as nonclostridial anaerobes has been debated for several decades and still remains open [11]. A comparison of the clinical details in a series of acute bacterial prostatitis after transrectal prostate biopsy described a higher incidence of sepsis and antibioticresistant bacteria in the post biopsy prostatitis group [12]. The low detection rate of prostate biopsy is determined by the lack of specificity of PSA that causes challenging diagnostic problems for urologists, additional morbidity and anxiety for patients and higher costs for health systems. Histological inflammation of the prostate is a very common finding in biopsy specimens of patients with an elevated PSA and no clinical evidence of prostatitis. Inflammation of the prostate is a recognized cause of PSA elevation in absence of PCa. Prostatic inflammation lead to a deterioration of the natural anatomic and physiologic barriers between the prostatic milieu and the bloodstream determining increased PSA levels [13]. Elevated values of serum PSA are not pathognomonic for prostate cancer but they can be found in various clinical conditions, including inflammation and infection. In men with an increasing PSA without clinical evidence of infection, a common clinical approach is to empirically prescribe antibiotics and subsequently re-dose the PSA. Until today, several researchers have examined the impact of empiric antibiotics therapy in patients with an increased PSA, in order to find a balanced costs/effective therapy to avoid unnecessary prostate biopsies and to decrease patient discomfort and morbidity from biopsy [14]. Prostate cancer is determined in only $34 \%$ of biopsies performed on the basis of PSA elevation and in $20-30 \%$ in patients with normal DRE and PSA values of between 4 and $10 \mathrm{ng} / \mathrm{mL}$. Therefore, there is a high level of unnecessary biopsies, particularly in this group [15]. However, increased PSA is also associated with conditions other than cancer, such as prostate inflammation, and prostatitis treatment has been shown to decrease PSA in a significant percent of such patients. Treatment of prostatitis with an antimicrobial and/or anti-inflammatory medication may provide a cost-effective approach to decrease the number of negative biopsies [16,17]. Our study will be dedicated for retrospective analysis of bacterial isolates in urine culture in patients with chronic bacterial prostatitis and levels PSA before and after antimicrobial treatment indicating on the important role investigation of pattern microorganisms in urine culture and levels PSA before antibiotic therapy in preventing unnecessary biopsy prostate in case of elevation in the range $4-10 \mathrm{ng} / \mathrm{ml}$.

\section{Materials and Methods \\ Study participants and criteria inclusion}

In our study was presented 125 patients in aged $30-83$ years with diagnosis of chronic bacterial prostatitis. We performed digital rectal examination, urine culture, transrectal ultrasound investigation of prostate, PSA analysis before and after antibiotic treatment and antimicrobial susceptibility testing. Criteria for inclusion in the trial were digital rectal examination without suspicion of urological cancers, absence of history of intravesical 
instrumentation and biopsy of prostate, values PSA in range from 4,0 to $11 \mathrm{ng} / \mathrm{ml}$, symptoms of chronic bacterial prostatitis, absence of abnormalities both upper and lower urinary tracts .

\section{Microbiological assessment and PSA analysis}

We collected midstream of urine from patients with chronic bacterial prostatitis for culture investigation. It was used for determination of taxonomic structure and quantity of isolated bacterial uropathogens. In order that to determine the quantity and type bacteria from each breeding produced seed ( $0.1 \mathrm{ml}$ each) on nutrient media: Endo, High Hrom selective agar for Candida fungi, High Hrom selective agar for enterococci, youlk soult agar , blood agar, prepared on the basis of Müller-Hinton agar with the addition of sheep erythrocytes. For non-clostridial bacteria were used: the Müller-Hinton environment with the addition of sheep erythrocytes, Blaurocca, agar and Shedler. The crops were incubated in aerobic and anaerobic (10\% CO2, 10\% H2, 80\% N2) conditions cultivation in temperature $37^{\circ} \mathrm{C}$. Identification of microorganisms carried out by morphological, tinctorial, cultural and biochemical traits. Midstream urine was obtained for urinalysis and culture using methods to isolate pathogens at $\geq 50 \mathrm{cfu} / \mathrm{mL}$. The antibiotic susceptibility testing was performed by the Kirby-Bauer's Disk Diffusion method in accordance with the CLSI guidelines. Susceptibility of isolated microorganisms determined to 35 antibiotics of different groups in aerobic and anaerobic conditions of cultivation. In our study PSA analysis was used for determination baseline level, excluding patients with values more than $11 \mathrm{ng} / \mathrm{ml}$ with suspicion on prostate cancer and also as a control of effectiveness of antibiotic treatment. For evaluation changes PSA before and after treatment we divided all patients on five groups with different regimen antimicrobial agents in according to results antibiotic susceptibility test.

\section{Digital rectal examination and transrectal ultrasound investigation}

All patients with chronic bacterial prostatitis underwent TRUS investigation with $10-\mathrm{MHz}$ biconvex transducer in regimen grey scale and colour Doppler for evaluation the condition of parenchyma prostate and excluding the patients with findings of prostate cancer such as massive calcification of parenchyma of prostate and disorganization of the vascular pattern with additional thickened and crimped vessels, presence of hypoechogenic tumor nodes in different parts of parenchyma prostate. Digital rectal examination of prostate was performed for all patients with chronic bacterial prostatitis with aim to rule out patients with any nodes which are suspicious for prostate cancer.

\section{Statistic analysis}

All data are expressed as mean \pm standard deviation (SD) with 95\% confidence interval. Parametric Student's t test and nonparametric Mann-Whitney $U$ test and $\chi 2$ test were performed for the differences in the mean ages, serum PSA level, prevalence

\begin{tabular}{|c|c|c|}
\hline Isolated microorganism & $\begin{array}{c}\text { Decimal logarithm of average level bacteriuria of } \\
\text { isolated microorganism }\end{array}$ & $\begin{array}{c}\text { Percentage bacteria from total number of } \\
\text { patients (\%) }\end{array}$ \\
\hline Corynebacterium spp & 1,8 & 44,8 \\
\hline Enterococcus spp & 3,5 & 40,8 \\
\hline Staphylococcus epidermidis & 1,5 & 29,5 \\
\hline Escherichia coli & 4,0 & 44 \\
\hline Veilonella spp & 1,9 & 24,4 \\
\hline Eubacterium spp & 3,2 & 47,2 \\
\hline Peptococcus spp & 1,5 & 37,6 \\
\hline Propionibacterium spp & 2,6 & 36 \\
\hline Prevotella spp & 1,5 & 3,2 \\
\hline Staphylococcus warneri & 1,0 & 2,4 \\
\hline Staphylococcus aureus & 1,8 & 12 \\
\hline Klebsiella spp & 3,2 & 12,8 \\
\hline Staphylococcus lentus & 1,5 & 7,2 \\
\hline Bacteroides spp & 2,7 & 5,6 \\
\hline Bacillus spp & 1,0 & 1,6 \\
\hline Megaspherae spp & 1,7 & 4,8 \\
\hline Staphylococcus haemalyticus & 1,9 & 20,8 \\
\hline Pseudomonas aeruginosa & 3,3 & 2,4 \\
\hline Proteus spp & 2,0 & 3,2 \\
\hline Peptostreptococcus spp & 2,1 & 10,4 \\
\hline Staphylococcus saprophyticus & 1,2 & 6,4 \\
\hline Streptococcus spp & 2,0 & 2,4 \\
\hline Fusobacterium spp & 2,2 & 4,8 \\
\hline Aeromonas hydrophila & 2,3 & 2,4 \\
\hline Morganella morganii & 2,5 & 1,6 \\
\hline Burkholderia sepacia & 1,2 & 3,2 \\
\hline Mobiluncus spp & 2,2 & 4 \\
\hline
\end{tabular}

Citation: Krakhotkin DV, Chernylovskyi VA, Najjar S, Alper G (2017) Pattern of Bacterial Isolates and Antimicrobial Susceptibility of Urine Culture in Men with Chronic Bacterial Prostatitis and Levels PSA Before and After Treatment. J Urol Nephrol Open Access 3(3): 
each kind of bacteria in urine culture between the patients. Twosided null hypotheses of no difference were rejected if $\mathrm{p}$ values were less than 0.05 . All analyses were performed using the SPSS software version 12.0

\section{Results}

\section{Microbiological results}

A total of 125 patients with chronic bacterial prostatitis and high level of PSA were estimated by culture of urine for determination spectrum of isolated microorganisms and pattern susceptibility to antimicrobial agents. The average (mean \pm standard deviation) age of all men in this study was $59.6 \pm 12.7$ years. Table 1 shows the prevalence types of the isolated microorganisms and mean level of bacteriuria for each uropathogen. In all patients the urine had the mixed bacterial infection and amongst of them predominated non-clostridial anaerobes and coagulase-negative staphylococci.
The non-clostridial, non-spore forming anaerobic microorganisms, the taxonomic structure of chronic bacterial prostatitis were more often represented by Peptococcus spp $(37,8 \%)$, Propionibacterium spp (36\%), Eubacterium spp $(47,2 \%)$, Veillonella spp $(24,4 \%)$ with average level of bacteriuria Log 1,5 CFU/ml , Log 2,6 CFU/ml, Log 3,2 CFU/ml, Log 1,9 CFU/ $\mathrm{ml}$, respectively. In the group of cougulase-negative staphylococci predominated S.epidermidis $(29,5 \%)$, S.haemalyticus $(20,8 \%)$, S.aureus (12\%) with mean level of bacteriuria Log 1,5 CFU/ $\mathrm{ml}, \log 1,9 \mathrm{CFU} / \mathrm{ml}, \log 1,8 \mathrm{CFU} / \mathrm{ml}$, respectively. The family Enterobacteriaceae was presented by E.coli (44\%) and Enterococcus spp $(44,8 \%)$ with mean level bacteriuria Log 4,0 CFU/ml and $\log 3,5 \mathrm{CFU} / \mathrm{ml}$, respectively. Figure 1 shows the prevalence of isolated bacteria from urine in patients with chronic bacterial prostatitis .

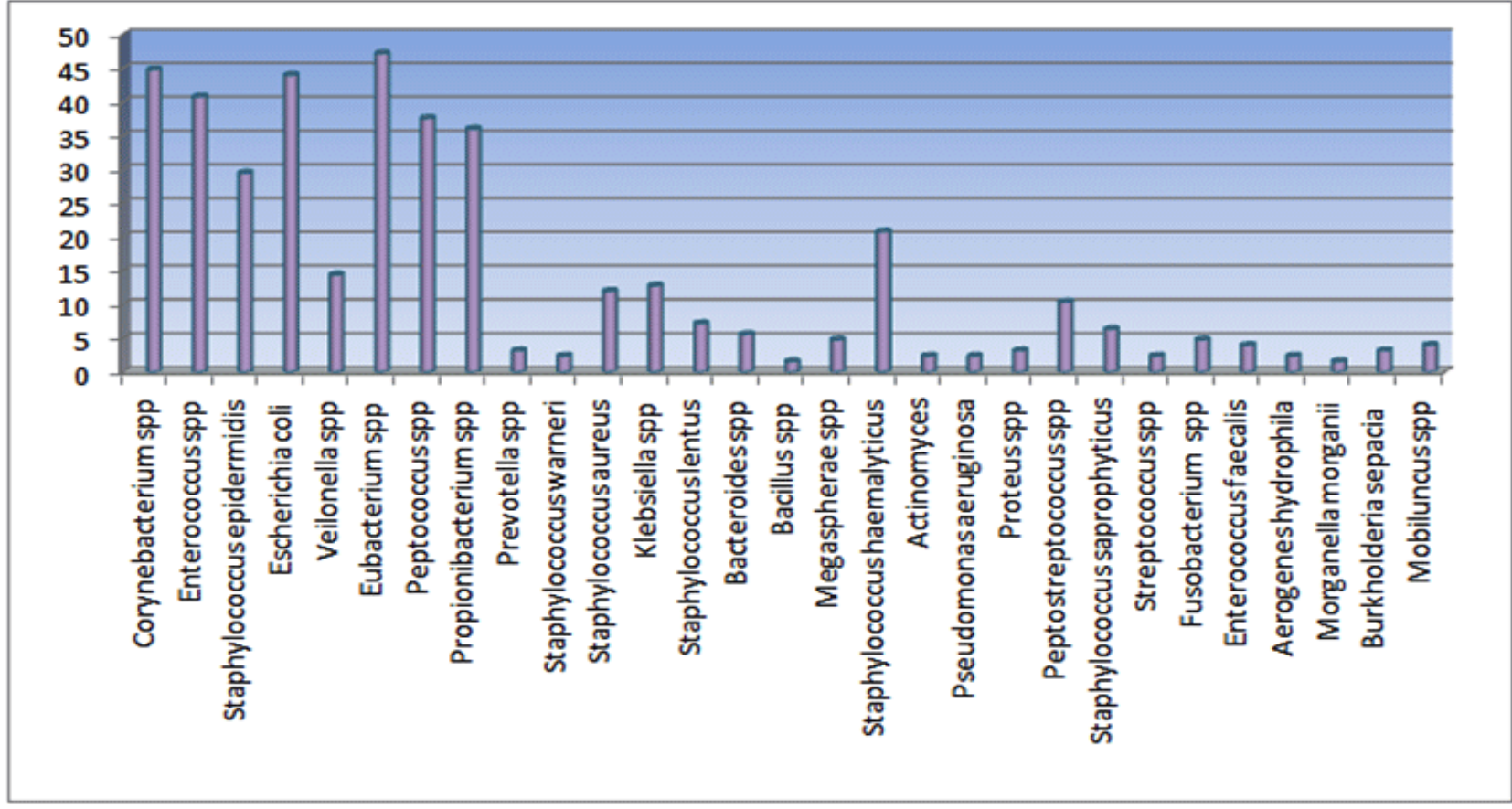

Figure 1:Prevalence of isolated bacteria from urine in patients with chronic bacterial prostatitis (\%)

A purely nonclostridial anaerobic infection without the participation of aerobic bacteria is rare. More often associations of 2-3 species of anaerobes with various representatives of aerobes are revealed. The most frequent combination of nonclostridial anaerobes was observed with coagulase-negative staphylococci or Corynebacterium spp. The etiological structure of isolated microorganisms were also presented by different gram-negative rods such as Klebsiella spp(12,8\%), Bacteroides spp(5,6\%),Mobiluncus spp (4\%), Burkholderia sepacia(3.2\%), Prevotella spp (3,2\%), Aeromonas hydrophila(2,4\%), Morganella morganii(1.6\%) with mean level bacteriuria $\log 3,2 \mathrm{CFU} / \mathrm{ml}$, Log 2,7 CFU/ml, Log 2,2 CFU/ml, Log 1,2 CFU/ml, Log 1,5 CFU/ml, $\log$ 2,3 CFU/ml, Log 2,5 CFU/ml, respectively.

\section{Results of antibiotic susceptibility testing}

A tIn our study susceptibility noted for following groups antibiotics: carbapenems, fluoroquinolones, aminoglycosids, cephalosporins, nitrofurans ,macrolids and protected penicillins . Amongst of them most active against bacterial pathogens isolated from urine in patients with chronic bacterial prostatitis were carbapenems, fluoroquinolones and cephalosporins in $90 \%$, $84 \%$ and $78 \%$ cases, respectively. The lowest sensitivity was in nitrofurans and macrolids in $32 \%$ and $45 \%$ cases, respectively. Above mentioned results are shown in Figure 2. 


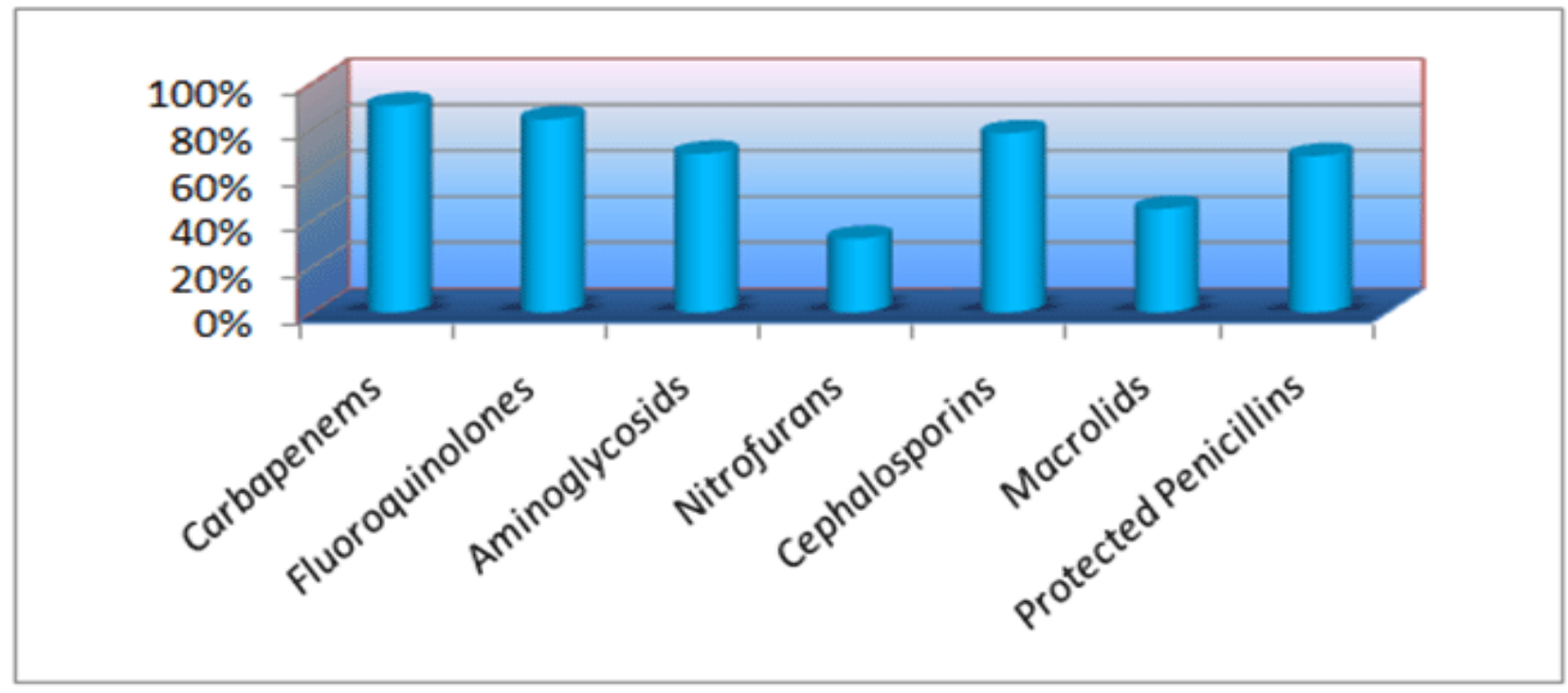

Figure 2: Susceptibility of isolated microorganisms to antimicrobial agents

PSA values after treatment in depending of chosen regimen combined antibiotic therapy and TRUS findings

In five groups patients which divided in depending from chosen regimen of combined antibiotic treatment in according results susceptibility testing to antimicrobial agents, the changes of level PSA were following : in I group (25 patients) 7,34 $2,6,95 \%$ CI [6.27-8.41] before and $2.26 \pm 1.02$, 95\% CI [1.842.68] after administration Imipenem $500 \mathrm{mg}$ IM bid for 7 days
+ Ciprofloxacin $500 \mathrm{mg}$ per os bid for 10 days ; in II group (22 patients) $7.20 \pm 1.76,95 \%$ CI (6.42-7.98) before and $1.8 \pm 0.84$, 95\% CI (1.43-2.17) after administration Levofloxacin $500 \mathrm{mg}$ per os once a day 14 days + Cefixime $400 \mathrm{mg}$ per os once a day 5 days ; in III groups (26 patients) 7.05 $\pm 1.35,95 \%$ CI (6.5-7.6) before and $1.57 \pm 0.89,95 \%$ CI (1.21-1.93) after administration Amikacin $500 \mathrm{mg}$ IM bid 7 days + Cefixime $400 \mathrm{mg}$ per os once a day 5 days ; in IV group (24 patients) $7.51 \pm 1.39,95 \%$ CI (6.92-8.1) before and $1.45 \pm 0.93,95 \%$ CI (1.29-1.61) after administration Amoxicillin/clavulanic acid $500 \mathrm{mg}$ bid 7 days + Levofloxacin

Table 2: Levels of PSA before and after treatment and regimens of used antimicrobial agents

\begin{tabular}{|c|c|c|c|c|}
\hline Group of patients & $\begin{array}{l}\text { Regimen of antibiotic } \\
\text { treatment }\end{array}$ & $\begin{array}{l}\text { Level of PSA before treatment } \\
\text { Mean } \pm \text { SD, } 95 \% \text { CI }\end{array}$ & $\begin{array}{l}\text { Level of PSA after } \\
\text { treatment } \\
\text { Mean } \pm \text { SD, } 95 \%\end{array}$ & $P$ value \\
\hline I (25) & $\begin{array}{l}\text { Imipenem } 500 \text { mg IM bid } 7 \\
\text { days + Ciprofloxacin } 500 \mathrm{mg} \\
\text { per os bid } 10 \text { days }\end{array}$ & $\begin{array}{l}7,34 \pm 2,6 \\
95 \% \text { CI }(6.27-8.41)\end{array}$ & $\begin{array}{l}2.26 \pm 1.02 \\
95 \% \text { CI }(1.84-2.68)\end{array}$ & $<0.05$ \\
\hline II (22) & $\begin{array}{l}\text { Levofloxacin } 500 \mathrm{mg} \text { per os once } \\
\text { a day } 14 \text { days + Cefixime } 400 \mathrm{mg} \\
\text { per os once a day } 5 \text { days }\end{array}$ & $\begin{array}{l}7.20 \pm 1.76 \\
95 \% \text { CI }(6.42-7.98)\end{array}$ & $\begin{array}{l}1.8 \pm 0.84 \\
95 \% \text { CI }(1.43-2.17)\end{array}$ & $<0.05$ \\
\hline III ( 26) & $\begin{array}{l}\text { Amikacin } 500 \mathrm{mg} \text { IM bid } 7 \text { days } \\
+ \text { Cefixime } 400 \mathrm{mg} \text { per os once a } \\
\text { day } 5 \text { days }\end{array}$ & $\begin{array}{l}7.05 \pm 1.35 \\
95 \% \text { CI }(6.5-7.6)\end{array}$ & $\begin{array}{l}1.57 \pm 0.89 \\
95 \% \mathrm{Cl}(1.21-1.93)\end{array}$ & $<0.05$ \\
\hline IV (24) & $\begin{array}{l}\text { Amoxicillin/clavulanic acid } 500 \\
\text { mg bid } 7 \text { days }+ \text { Levofloxacin } \\
500 \text { mg once a day per os } 14 \\
\text { days }\end{array}$ & $\begin{array}{l}7.51 \pm 1.39 \\
95 \% \operatorname{CI}(6.92-8.1)\end{array}$ & $\begin{array}{l}1.45 \pm 0.93 \\
95 \% \mathrm{Cl}(1.29-1.61)\end{array}$ & $<0.05$ \\
\hline$V(28)$ & $\begin{array}{l}\text { Imipenem } 500 \mathrm{mg} \text { IM bid } 7 \text { days } \\
+ \text { Cefixime } 400 \mathrm{mg} \text { per os once a } \\
\text { day } 5 \text { days }\end{array}$ & $\begin{array}{l}7.11 \pm 1.16 \\
95 \% \text { CI }(6.65-7.56)\end{array}$ & $\begin{array}{l}1.48 \pm 0.86 \\
95 \% \mathrm{CI}(1.15-1.81)\end{array}$ & $<0.05$ \\
\hline
\end{tabular}


$500 \mathrm{mg}$ once a day per os 14 days; in $\mathrm{V}$ group (28 patients) 7.11 $\pm 1.16,95 \%$ CI (6.66-7.56) before and 1.48 $0.8695 \%$ CI (1.151.81) after administration Imipenem $500 \mathrm{mg}$ IM bid 7 days + Cefixime $400 \mathrm{mg}$ per os once a day 5 days. Above mentioned results of changes PSA level before and after antibiotic treatment are shown in Table 2.

After treatment repeat urine culture did not show any uropathogens indicating on microbiological eradication in all 5 groups patients with different regimen of treatment. In all patients with chronic bacterial prostatitis and urine culture positive for bacterial mixed infection transrectal ultrasound investigation of prostate with colour Doppler showed typical changes such as diffuse or local enforcement of blood flow in the branches of prostatic arteries (urethral and capsular), diffuse or local decrease of echogenecity of parenchyma of prostate, sites of fibrosis with impoverishment of vascular pattern (figure 3). After 3 and 6 months we performed the repeat measurement of level PSA and there was no any elevation higher than $>4 \mathrm{ng} / \mathrm{ml}$.

In our study the patients with level PSA $>11 \mathrm{ng} / \mathrm{ml}$ which did not change after treatment and suspicious data on prostate cancer during transrectal ultrasound investigation and digital rectal examination were excluded.

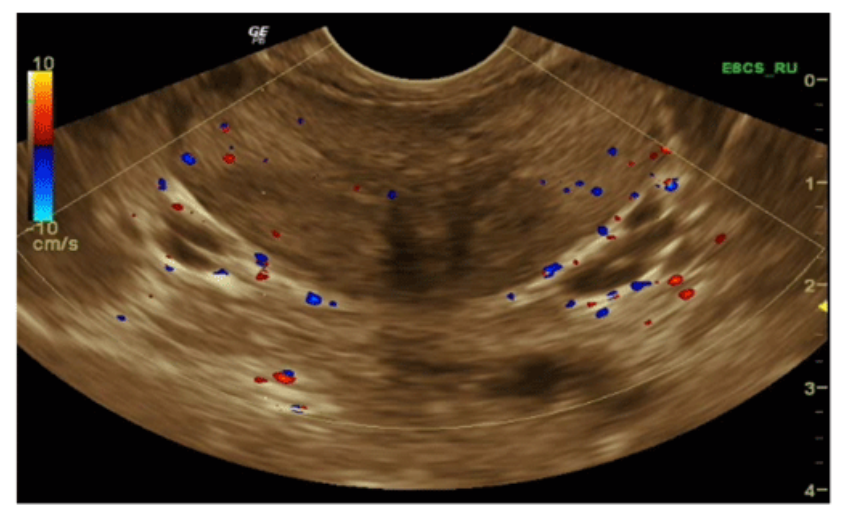

Figure 3: Data of transrectal ultrasound investigation of prostate in patient with chronic bacterial prostatitis

\section{Discussion}

This study demonstrated that administration of antibiotic therapy can lead to subsequent decrease level PSA for all examined regimens of antibiotics in according to results of test for susceptibility to antibiotic. There was significant decrease of level PSA after administration of antimicrobial agents in all 5 groups with different regimen of antimicrobial treatment. Schaeffer et al in one study demonstrated decrease the level PSA to normal range after administration fluoroquinolones and microbiological eradication. In according to our results more preferably to describe combined therapy with fluoroquinolones due to their known pharmacokinetic characteristic. In concerning to results of urine culture the etiological structure of isolated microorganisms in urine was presented by mixed bacterial infection and amongst of them predominated non-clostridial anaerobes and coagulasenegative staphylococci. The representatives of Enterobacteriaceae and Corynebacterium were also the most common uropathogens in study population of men with chronic bacterial prostatitis with prevalence for E.coli (44\%), Enterococcus spp(40,8\%) and Corynebacterium spp $(44,8 \%)$, respectively. With PSA routine screening, the number of patients diagnosed with PSA in the "gray zone" has been increasing rapidly. However, due to conditions such as cancer, inflammation and benign hyperplasia with overlapping low PSA levels, the positive rate hovered around approximately $20 \%$ [18]. Agnihotri et al, had higher cancer detection rate overall (57.5\%) and also for serum PSA ranges of (4-10) and (10-20) ng/ $\mathrm{ml}$, which was $43.35 \%$ and $36.57 \%$ respectively, irrespective of DRE findings. They had suggested raising the serum PSA cut off in symptomatic men with negative DRE for TRUS biopsy in India to $5.4 \mathrm{ng} / \mathrm{ml}$ to avoid $10 \%$ unnecessary biopsies [19].

Our results showed that administration combined antibiotic therapy decreased the value PSA up to normal range in all study groups. The most pronounced decline was noted in IV and V groups. In literature there are a lot of studies about of screening prostate cancer in patients who have the values of level PSA in the "gray zone" and some of them reported that PCa detection rate was $25-35 \%$ but in clinical practice there are situation when biopsy of prostate is described based on value PSA in range 4-10 $\mathrm{ng} / \mathrm{ml}$ and after that results of biopsy showed in all specimens chronic inflammation without signs of prostate cancer thereby aggravating the inflammatory process without antibiotic prophylaxis before the procedure.

In our study we emphasized about of necessity to examine etiological structure of isolated pathogens in urine culture with subsequent susceptibility antibiotic testing and periodical measurement level PSA and using other urinary biomarkers such as Prostate Index Health, prostate cancer antigen 3, TMPRESS (transmembrane protease, serine 2) during follow-up in order that to avoid unnecessary biopsy and not to miss risk of development of PCa in further.

\section{Conclusions}

In patients with baseline level PSA in range $4-10 \mathrm{ng} / \mathrm{ml}$ provided that possibility of prostate cancer is excluded by digital rectal examination and transrectal ultrasound investigation, administration of combined antibacterial therapy with fluoroquinolones in account of pattern of isolated microorganisms and results susceptibility to antibiotic can lead to significant decrease level PSA and microbiological eradication pathogens and to avoid unnecessary biopsies of prostate.

\section{References}

1. Los-Arcos I, Pigrau C, Rodríguez-Pardo D, Fernández-Hidalgo N, Andreu A, Larrosa N, et al. Long-Term Fosfomycin-Tromethamine Oral Therapy for Difficult-To-Treat Chronic Bacterial Prostatitis. Antimicrob Agents Chemother. 2015;60(3):1854-1858. doi: 10.1128/AAC.02611-15

2. Gill BC, Shoskes DA. Bacterial prostatitis. Curr Opin Infect Dis. 2016;29(1):86-91. doi: 10.1097/QC0.0000000000000222 
3. Stamatiou K, Pierris N. Mounting resistance of uropathogens to antimicrobial agents: A retrospective study in patients with chronic bacterial prostatitis relapse. Investig Clin Urol. 2017;58(4):271-280. doi: 10.4111/icu.2017.58.4.271

4. Alyaev Yu.G., Vinarov AZ, Pshikhachev A.M. Chronic a bacterial prostatitis: Do we all know? Andrology and genital surgery. 2010;3:90-94.

5. Khan FU, Ihsan AU, Khan HU, Jana R, Wazir J, Khongorzul P, et al. Comprehensive overview of prostatitis. Biomed Pharmacother. 2017;94:1064-1076. doi: 10.1016/j.biopha.2017.08.016

6. Kim SH, Ha US, Yoon BI, Kim SW, Sohn DW, Kim HW, et al. Microbiological and clinical characteristics in acute bacterial prostatitis according to lower urinary tract manipulation procedure. J Infect Chemother. 2014;20(1):38-42. doi: 10.1016/j.jiac.2013.11.004

7. Yoon BI, Kim S, Han DS, Ha US, Lee SJ, Kim HW, et al. Acute bacterial prostatitis: how to prevent and manage chronic infection? J Infect Chemother. 2012;18(4):444-450. doi: 10.1007/s10156-011-0350-y

8. Bartoletti R, Mondaini N, Pavone C, Dinelli N, Prezioso D.et al. Introduction to chronic prostatitis and chronic pelvic pain syndrome (CP/CPPS). Arch Ital Urol Androl. 2007;79(2):55-57.

9. Stamatiou K, Karageorgopoulos DE. A prospective observational study of chronic prostatitis with emphasis on epidemiological and microbiological features. Urologia. 2013;80(3):225-232. doi: 10.5301/urologia.5000024

10. Rodríguez MA, Afari N, Buchwald DS; National Institute of Diabetes and Digestive and Kidney Diseases Working Group on Urological Chronic Pelvic Pain. Evidence for overlap between urological and nonurological unexplained clinical conditions. J Urol 2009;182(5):2123-2131. doi: 10.1016/j.juro.2009.07.036

11. Ibishev, et al. The microbiological spectrum and antibiotic sensitivity of uropathogens isolated from chronic bacterial prostatitis. Effective pharmacotherapy. Urology. 2012.

12. Kim JW, Oh MM, Bae JH, Kang SH, Park HS, Moon du G. Clinical and microbiological characteristics of spontaneous acute prostatitis and transrectal prostate biopsy-related acute prostatitis: Is transrectal prostate biopsy-related acute prostatitis a distinct acute prostatitis category? J Infect Chemother. 2015;21(6):434-437. doi: 10.1016/j jiac.2015.01.014
13. Gallo L. The Effect of a Pure Anti-inflammatory Therapy on Reducing Prostate-specific Antigen Levels in Patients Diagnosed With a Histologic Prostatitis. Urology. 2016;94:198-203. doi: 10.1016/j. urology.2016.05.015

14. Fandella A, Benvenuto S, Guidoni E, Giampaoli M, Bertaccini A. Empiric antibiotics therapy for mildly elevated prostate specific antigen: Helpful to avoid unnecessary biopsies? Arch Ital Urol Androl. 2014;86(3):202-204. doi: 10.4081/aiua.2014.3.202

15. Busato WF, Almeida GL, Geraldo J, Busato FS. Does PSA reduction after antibiotic therapy permits postpone prostate biopsy in asymptomatic men with PSA levels between 4 and $10 \mathrm{ng} / \mathrm{mL}$ ? Int Braz J Urol. 2015;41(2):329-36. doi: 10.1590/S1677-5538. IBJU.2015.02.21

16. Karazanashvili G, Managadze L. Prostate-specific antigen (PSA) value change after antibacterial therapy of prostate inflammation, as a diagnostic method for prostate cancer screening in cases of PSA value within 4-10 $\mathrm{ng} / \mathrm{ml}$ and nonsuspicious results of digital rectal examination. Eur Urol. 2001 May;39(5):538-543. doi: 52500

17. Schaeffer AJ, Wu SC, Tennenberg AM, Kahn JB. Treatment of chronic bacterial prostatitis with levofloxacin and ciprofloxacin lowers serum prostate specific antigen. J Urol. 2005;174(1):161-164. doi: 10.1097/01.ju.0000162017.24965.2b

18. Inahara M, Suzuki H, Kojima S, Komiya A, Fukasawa S, Imamoto T, et al. Improved prostate cancer detection using systematic 14-core biopsy for large prostate glands with normal digital rectal examination findings. Urology. 2006;68(4):815-819.

19. Agnihotri S, Mittal RD, Kapoor R, Mandhani A. Raising cut-off value of prostate specific antigen (PSA) for biopsy in symptomatic men in India to reduce unnecessary biopsy. Indian J Med Res. 2014;139(6):851-856. 